\title{
Crusoe, Friday and the Raced Market Frame of Orthodox Economics Textbooks
}

\section{Matthew Watson}

To cite this article: Matthew Watson (2018) Crusoe, Friday and the Raced Market Frame of Orthodox Economics Textbooks, New Political Economy, 23:5, 544-559, DOI: 10.1080/13563467.2017.1417367

To link to this article: https://doi.org/10.1080/13563467.2017.1417367
(c) 2018 The Author(s). Published by Informa UK Limited, trading as Taylor \& Francis Group

曲 Published online: 05 Jan 2018.

Gubmit your article to this journal 4

Џلll Article views: 743

View Crossmark data ¿ 


\title{
Crusoe, Friday and the Raced Market Frame of Orthodox Economics Textbooks
}

\author{
Matthew Watson \\ Politics and International Studies, University of Warwick, Coventry, UK
}

\begin{abstract}
'Crusoe' and 'Friday' signifiers necessarily evoke a world of racialised hierarchies. Economics textbooks are perhaps the sole remaining medium to simply wish away their resulting relations of power. These are the teaching aids that inspire students analytically to think of markets as pristine economic institutions and persuade them politically that they should want to will such institutions into being. Yet they alltoo-often rely on the pedagogical device of the so-called Robinson Crusoe Economy, where the main characters from Defoe's most famous novel are required to instinctively recognise their equality within voluntary contracting agreements so that each can act as the neoclassical homo economicus. In other words, economists' Crusoe and Friday figures must behave antithetically to what has historically been implied by the 'Crusoe' and 'Friday' signifiers. But how can this be so, given how commonplace it was when Defoe's characters were first introduced into economic theory in the 1850 s to justify white settler colonialism on the grounds that 'savage' societies lacked the capacity to be self-governing? The raced market frame that emerged in practice from this assumption continues to be reproduced uncritically today by Crusoe's and Friday's presence in the textbook explanation of the most basic model of market exchange.
\end{abstract}

\section{ARTICLE HISTORY}

Received 21 November 2017 Accepted 5 December 2017

\section{KEYWORDS}

Crusoe and Friday; Defoe; Campe; neoclassical homo economicus; raced markets

\section{Introduction}

The publication in 1719 of Daniel Defoe's Robinson Crusoe is typically treated as the originating moment of the specifically individualistic English novel (Watt 1974: 60). ${ }^{1}$ Unusually for the time, its central character was animated by neither love nor honour, but by straightforward economic self-preferment (Grapard 1995: 42). It was this sense of priority that made Crusoe so attractive to the early marginalist economists a century and a half later. However, the rise of the English novel is inseparable from the rise of the British Empire, occurring at the same time and being framed by the same political mindset (Said 1994: 70). Crusoe acts as if it is simply his right of being born English to take as his possession everything he encounters after his shipwreck on the island. It is his white colonist's unqualified claim on property that has subsequently brought the story to the attention of a later generation of postcolonial writers. The fact that he has no doubts about the legitimacy of extending his claim on property to include Friday has proved particularly susceptible to postcolonial critique (Naipaul 2002: 304). The original novel was written as an imperial fantasy, and in Defoe's hands Crusoe's economic individualism is indivisible from his status

CONTACT Matthew Watson $\otimes$ matthew.g.watson@warwick.ac.uk $\mathrm{P}$ Politics and International Studies, University of Warwick, Coventry CV4 7AL, UK 
first as a colonial settler and then as a colonial master. The 'Crusoe' and 'Friday' signifiers are now so culturally familiar as symbols of a prior imperial age that the recognition of how unreflexively they continue to be used in economics textbooks today still comes as something of a shock. It is difficult to understand the thought process that allows Defoe's characters to be presented as paragons of individualism whilst having had all of their accompanying imperial history assumed away. At a time of unparalleled demands across the social sciences for the curriculum to be decolonised, surely economics students deserve rather more from their textbooks.

Admittedly, by no means all textbooks present the actions of an abstract homo economicus directly in the person of Crusoe and Friday figures. But even when this is not the case the examples of how the neoclassical homo economicus solves problems of constrained maximisation always have close to the surface the image of isolated individuals cut off from the rest of society (Hewitson 1999: 111). As soon as you have seen the neoclassical homo economicus named after Defoe's most famous characters, it is very difficult not to call to mind Crusoe and Friday figures on future occasions even when the textbook puzzles are solved using people with altogether different names. Crusoe is simply too synonymous with the shipwrecked sailor, Friday with the enslaved 'companion'. The economics textbooks thus tap into childhood retellings of Defoe's story that emphasise Crusoe's heroic struggle to survive against all odds. It takes little to imagine Crusoe's situation on the island as a game against nature in which he has to make the best of what is at hand.

This setting is endlessly repeated in the textbooks: 'Let's begin our analysis ... by imagining Robinson Crusoe, stranded and alone on an island' (Gottheil 2013: 30); 'Robinson Crusoe lives on a desert island' (Basov 2017: 51); 'Robinson Crusoe, who is stranded on an island after a shipwreck' (Mankiw and Taylor 2006: 50); 'Even Robinson Crusoe had to deal with economic issues on his deserted island' (Musgrave and Kacapyr 2001: 23). From here it is just a small step to follow the early marginalists in claiming that if he is to make life more tolerable for himself by securing the conditions of his future survival efficiently, then he must have an incentive to maximise on the margin (see Snowdon and Vane 2005: 310). Such actions have been described in the textbooks in the following way:

In the classic Robinson Crusoe economy, all production and all consumption is carried out by a single consumer. Robinson the consumer sells his labour time $h$ (in hours) to Robinson the producer, who in turn uses the consumer's labour services for that amount of time to produce coconuts, $y$, which he then sells to Robinson the consumer. (Jehle and Reny 2011: 226)

The same point has also been made less formally: 'Robinson can spend his time loafing on the beach thereby consuming leisure, or he can spend time gathering coconuts. The more coconuts he gathers the more he has to eat, but the less time he has to improve his tan' (Varian 2014: 628-9). As the early marginalists Gossen, Menger, Jevons, Böhm-Bawerk, Edgeworth, von Wieser, Wicksteed, Marshall and Clark conducted their search for standard bearers for their new economic theory in the late nineteenth century, it was the presumed economic efficiency that Crusoe implanted in both himself and Friday that really leapt off the pages of Defoe's novel and its eighteenth-century rewritings (White 1998: 217). It is clear from the examples cited above that exactly the same assumption continues to be used frequently in economics textbooks even today.

However, the distinguishing feature of agents who maximise at the margin in economic theory is that they have had all of their history taken away from them. They are required to exist in a hypothetical realm that is somehow outside the structures of everyday political socialisation, so that they can be governed by purely economic impulses. This is what the early marginalists saw in Crusoe's attempts to come to terms with his new circumstances as a castaway. But it is also what later postcolonial writers have deemed impossible due to the 'Crusoe' signifier necessarily remaining a captive of Defoe's imperial imagination (Hymer 1971: 17). Crusoe might well have spent 28 years on the island in physical isolation from the society that had shaped his expectations, but this was by no means matched by psychological isolation (Watson 2010: 610-11, 2017: 89-90). He remained nothing other than true throughout his exile to the populist conception of empire that was then all the rage back home (Weaver-Hightower 2007: 31). 
The aim in what follows is to enforce a direct confrontation between the two Crusoes: the economists' Crusoe, who lives in his own bubble of constrained maximisation problems, and Defoe's Crusoe, who carries his society's assumptions around with him wherever he goes. Defoe's racist plot lines have left a lasting impact on the meaning that is denoted by the 'Crusoe' and 'Friday' signifiers, but economics textbooks use those same signifiers without a moment's reflection about the broader structure of Defoe's story. There is a need to be realistic about what might come from gaining deeper knowledge of the key passages through which the original Crusoe outlines the type of person he considers himself to be. I have no expectation that this will lead to a wholesale removal from economics textbooks of Crusoe and Friday figures, because they have become far too important to teaching the neoclassical principles of market exchange to simply be discarded. However, if we wish to explore what it would take to successfully decolonise economic concepts, then there can be no better way of starting than by exploring the relationship between market theory and early eighteenth-century assumptions about empire. If that theory can only be illustrated through reference to a white colonist whose instinct is always to subjugate the 'native' population, must we conclude that the economics textbooks, even if only unwittingly, reproduce a raced market frame?

In an attempt to examine this possibility, the remainder of the article now proceeds in three stages. In the first section, I explore what it was that the early marginalists saw in Defoe's characters and the uses to which they were consequently put. It was the desert island setting that appealed most obviously, because they thought that this provided a convenient approximation of the context in which their theories would work (Söllner 2016: 36). Here, and perhaps only here, Crusoe and Friday could focus their decisions on what was best for them individually, and they could subsequently come together in voluntary contracting agreements on that basis alone. They could therefore inhabit pristine market institutions and act out the behavioural attributes of the archetypal neoclassical homo economicus (Shackle 1992: 98). However, the second and third sections revisit Defoe's novel to reveal just how misleading these first impressions can be. Crusoe and Friday came to economics via a somewhat circuitous route through which many of the details of Defoe's original novel were overwritten, but the 'Crusoe' and 'Friday' signifiers remained wholly intact. Simply because of the associations implied by their names, it is impossible to use them as illustrations of a world in which racialised social standing makes no difference to how one may act within the market arena. They carry a history of racial domination which ensures that, as teaching aids, they might only be able to speak to a distinctly raced market frame.

There is much at stake here. Economics currently exists in a prolonged state of limbo. The feeling has perhaps never been more intense outside the field that its market models have failed and that its homo economicus construction leads only to a conceptual cul-de-sac. The fact that the institutions cast in the image of pristine market models and pristine market actors imploded during the global financial crisis continues to erode its external reputation (Keen 2013: 230). Within economics, though, much has remained the same in the way that the foundations of the subject are both conceptualised and taught. The textbooks today look remarkably similar to those of 10 years ago (Kates 2011: 11). Something akin to Crusoe and Friday figures continues to provide the basis of the behavioural theory through which the essence of acting within market environments is projected. The analysis in the following pages presents further objections to the presence in both economic theory and real-life market institutions of the neoclassical homo economicus. His instantiation through the 'Crusoe' and 'Friday' signifiers shows him to have been a product of the same racialised ideology that supported the European struggle for empire. It is therefore troubling that orthodox economics pedagogy still has no obvious alternative on which to construct its theory of market exchange.

\section{Defoe's novel in the context of the marginalist revolution}

Defoe wrote in a self-consciously 'realistic' register, charting his hero's painstaking struggles to ensure that hard work pays rich dividends in his imperial fantasy. The otherwise suffocating attention to 
detail shows how Crusoe-the-adventurer instinctively turned his attentions to becoming Crusoe-thesettler upon being cast away. Defoe happily required his early eighteenth-century middle-class English readers to confront the lengths to which his shipwrecked hero goes to profit financially as soon as the realisation dawns that being alone on the island equates to also being the 'lord of all this country indefeasibly' (114). ${ }^{2}$ The story is told in first-person format from Crusoe's perspective, but it is rare for autobiographical writings to be so obsessed with the specifics of day-to-day drudgery. It is the lessons from these struggles for survival that the early marginalists took to be exemplary of Crusoe's overall approach to acting 'economically' in the most literal of senses (see Mas-Colell et al. 1995: 526 for one such reading). He is presented as the marginalist ideal-type of the 'Choosing Man' (McCloskey 1996: 123), intuitively 'doing the best he can' with available resources, technology and expertise (Nechyba 2011: 546).

The textbook treatment of the history of economic thought tends to present the late nineteenthcentury shift to marginalism as if it was a historical inevitability. At the time, though, its future looked much less assured. The correspondence from the 1870s of Stanley Jevons, Carl Menger and Léon Walras - marginalism's ostensible 'founding fathers' - reveals their constant frustration at being lone voices in the wilderness. They were attempting to re-centre economics as the study of how an abstract individual makes choices framed by constrained maximisation problems. This is still what counts as mainstream economics today, and it receives institutional support from the neoliberal restructuring that has isolated the individual from a sense of belonging to a broader social grouping (see Crouch 2016: 139). Yet it proved to be highly controversial in its day (see Tarascio 1972: 425; Hutchison 1973: 176; Leijonhufvud 1976: 86). Pre-marginalist economic theory was based on an account of production that acknowledged the political realities of a class-riven society. It was relatively straightforward for anyone to recognise themselves within such an account. Marginalist economic theory, meanwhile, described the actions of a wilfully abstracted individual who has no position within society whatsoever. Its pioneers came under considerable pressure from proponents of what was then the orthodoxy to name someone - anyone - who might be able to live as their favoured economic subject, the neoclassical homo economicus. Crusoe was seized upon to fill the gap. It was assumed that he spoke to the image of 'an isolated individual' who is necessary for solving constrained maximisation problems in a formally economising manner, and such an assumption still holds sway today (see Barro 1997: 23). The early marginalists attempted to work with a strippeddown Crusoe figure who has total power of self-determination on the desert island. By eliminating the need to consider how other people's interests might impact upon his own, his status as shipwreck victim enables him to behave just as the neoclassical homo economicus would be expected to do. It is really quite remarkable that so little has changed today in this specific regard, despite the myriad advances in economic theory over the succeeding 150 years.

Yet the initial introduction of a Crusoe figure into economic theory came from an obscure source. Hermann Heinrich Gossen (1983 [1854]: 54) had anticipated his more celebrated successors by nearly 20 years when writing in the 1850 s that his new subjective theory of value had its most obvious manifestation in 'Robinson Crusoe, up to the point when Crusoe finds Friday'. This important pre-emption only came to light when Jevons (2013 [1871/1911]: liii-Ix) acknowledged Gossen's right to scientific priority in the 1879 second edition of his Theory of Political Economy. Having been directed in correspondence to the possibility that he may indeed have had a forerunner, he immediately embraced Gossen's identification of Crusoe as the neoclassical homo economicus. In outlining his own theory of value, Jevons (2013 [1871/1911]: 80) wrote that: 'Even Robinson Crusoe must have looked upon each of his possessions with varying esteem and desire for more, although he was incapable of exchanging with any other person'. Teresa Michals suggests that the adoption of the Crusoe name assisted Jevons in his struggle against the English Historical School, whose members' own more inductively based economic theory often led them to ridicule the marginalists' purely hypothetical account of economic behaviour. In Michals's (2014: 52) words, Crusoe 'provided a friendly face' for the homo economicus abstraction. His familiarity came from how well known Defoe's basic story was to European readers by the 1870s, which makes it interesting that it was not Defoe's Crusoe per se that Gossen had originally 
hailed when searching for a named someone to populate his new theory of value. 'In order to become fully convinced [of the adequacy of that theory]', to quote him more thoroughly, 'one needs only to read Campe's tale for the young, Robinson Crusoe, up to the point when Crusoe finds Friday' (Gossen 1983 [1854]: 54).

Joachim Heinrich Campe was a late eighteenth-century German educationalist and author of what is usually considered to be the most exhaustive pedagogical handbook of the Enlightenment (Fuchs 2004: 160). Running to 16 volumes, it advocated what Lorraine Daston (2004: 109) has called 'the cult of attention', whereby the essence of children comes to be determined in the same way as the essence of natural phenomena: that is, through the obsessive recording of observations. Campe followed his predecessors at the Philanthropinum, an experimental school in Dessau, in being opposed to instruction through disciplined memorisation (Sharma 2007: 76). Instead, he introduced ideas about learning readiness so that children could indicate through their actions when they were ready to progress to the next level of instruction (Bowen 1981: 200). Campe's most popular works were his travel stories for children, through which he attempted to harness narratives about nature encountered in faraway places to the formation of appropriate adult personality (IdelsonShein 2014: 156).

Pride of place in this regard must go to his systematic rewriting of Robinson Crusoe as Robinson der Jüngere, which turned Defoe's original novel into a story for children. Yet even though Campe worked within the plot structure represented by the original 'Crusoe' and 'Friday' signifiers, he changed the original ideological purpose of reading the book (Shavit 2006: 38). Campe may well have inserted a Christian God to speak through his text on almost every page, but this is not to oversee personal redemption through a commitment to the economic activities that Defoe's Crusoe undertakes to turn his island into a profitable colonial possession. Rather, Campe's (1789: 86) Christian God insists that due respect is paid to education. However, it is important not to overstate the differences, because this would seem to be one of those occasions when everything has been rewritten but precious little has actually changed. After all, Campe could have chosen any combination of character and context for eulogising devotion to study, and a shipwrecked sailor on a Caribbean island does not spring instantly to mind as the most likely environment for illustrating the need for diligence in learning. Gossen (1983 [1854]: 54) might well have said that Campe's Crusoe was particularly suited to incorporation into economic theory before the point at which he shared the island with Friday. Yet this element of the text works in its own terms only as preparation for the time at which Crusoe no longer lacks company. Campe turned Crusoe into a convert to the power of education, but he was denied an object for his new-found evangelism when he remained all alone. In his version of the story Crusoe is required to recount his regret for the wastefulness of his youth, specifically so that he can imagine his former self as a blank space that can be filled in through a commitment to learning. This, though, is merely the precursor for treating Friday as an equally blank space that it is both his personal responsibility and his European right to remake from scratch.

The Caribbean island setting is therefore fundamental to the ideological objectives to which he put the Crusoe figure to work, because Crusoe can only fulfil his European destiny if he has a black person that he can treat as his possession and bend to his will. As Susanne Zantop (1997: 105-6) notes, the whole of the Campe oeuvre is one

in which education is metaphorically equated with colonization and colonization with education, the domestication of little savages. As Robinson colonizes his Freitag on the island, creating the perfect colonial society, so Father Campe educates, colonizes, and colonializes his young audience to prepare them for their role as future colonizers.

In recommending that Campe's Crusoe stands in for the neoclassical homo economicus, then, Gossen did nothing to corrupt the racialised hierarchy inherent in Defoe's original 'Crusoe' and 'Friday' signifiers, even if he thought that the 'Crusoe' signifier could be taken in isolation.

It is, of course, impossible to replay intellectual history to see what would have happened had Campe's Crusoe not been initially enlisted by Gossen to fill the role of the neoclassical homo 
economicus. But this is no reason not to examine his significance in securing both the analytical and the ideological structure of neoclassical economics. It is notable in the first place just how quickly the historical school's objections to marginalism's abstractions were sidelined once the second generation marginalists had fleshed out the contribution to their way of thinking that a Crusoe figure could make. He continues to provide economics textbooks with a theory of behaviour that has become the template for an increasing number of everyday practices under the politics of neoliberalism (Karagöz 2014: 11). He also continues to provide economics textbooks with a theory of exchange that supports contemporary market ideology.

However, it remains very difficult to decouple the 'Crusoe' signifier from the white adventurerturned-settler who plays out Defoe's imperial fantasies. As was demonstrated by the earlier quotes, some economics textbooks have attempted to get around this problem by developing a theory of exchange in which a Crusoe figure populates both sides of the market simultaneously. The hope is that this might provide Crusoe with an 'everyman' status in which his characterisation no longer owes anything to either Defoe or Campe and is therefore taken out of their pro-imperial morality tales. Yet this works only by insisting that Crusoe-the-consumer and Crusoe-the-producer have no communication with one another (see Hirshleifer et al. 2005: 424 and Varian 1992: 349 for two further examples). One part of his divisible self has to decide how much labour he must contract if his optimised consumption plan is to be realised, whilst the other part of his divisible self has to decide how much of his own labour he will allow to be contracted in situations where he will always have a rational preference for leisure over work (Laidler and Estrin 1989: 403). The ensuing market conditions are clearly based on a definitional trick. Other economics textbooks have therefore introduced Friday into their account of the exchange relation, so at least the two sides of their market models are independently populated (e.g., Silberberg 1995: 185; Stinespring 2002: 179; Beveridge 2013: 3). Crusoe and Friday might well enable those market models to acquire pristine characteristics in abstract analytical terms. But the same cannot be true in political terms. Defoe placed them in a clear racialised hierarchy that Campe merely reinforced. Knowing the provenance of the 'Crusoe' and 'Friday' signifiers makes for uncomfortable reading when they are used devoid of context as a means of naturalising market ideology in the minds of economics students.

\section{Friday's transposition from Defoe's novel to the marginalist theory of market exchange}

The narrative structure of Defoe's Robinson Crusoe prioritises the white colonist's perspective. The story is undoubtedly about him, told in a first-person account written through his eyes, using his language and signed off in his name. Friday might also have had some compelling insights to share about his experiences as the clear subordinate in a racially divided two-person economy, but Defoe's reader is left to wonder what these might be. If an event does not happen to Crusoe and if it has no relevance to his attempts to secure redemption through enhancing the commercial value of the island, then from Defoe's perspective it is as if it does not happen at all. As Daizal Samad (2003: 346) suggests, Friday is thus reduced to a 'ghostly presence in his own land'. Something like a Friday figure is essential if Defoe's and Campe's plot lines are to work in their own terms, but in being denied the ability to be the narrator of his own history he has no significance in either story as a person. According to Roman Silvani (2012: 79), he is their 'central void'.

The economics textbooks also render Friday's self-understanding inconsequential, but in a markedly different way. With very few exceptions, they do so by assigning him the same rights under contract law as Crusoe enjoys. Neither is in any way special because both are representations of a supposedly universal norm, and lacking exceptionality neither needs to have his voice heard. It was Edgeworth's Mathematical Psychics that, in 1881, first used 'Crusoe' and 'Friday' signifiers in this way. He built upon Gossen's and Jevons's lead in appropriating Crusoe for their theory of economic behaviour by fleshing out the marginalist theory of exchange using both Crusoe and Friday. Edgeworth's contract curve concept depicts an imaginary frontier by joining up with a single line 
all the points of feasible exchange where both parties will consent to the exchange because it allows them to do as well as possible from their initial allocation of resources (Morgan 2012: 112). In a section of Mathematical Psychics revealingly entitled, 'Pure Contract', he invited his readers to call to mind 'a simple case - Robinson Crusoe contracting with Friday' (Edgeworth 2003 [1881]: 28).

In what comes next, though, there is no reference of any nature to the very different starting positions from which their exchange relationships begin in either Defoe's novel or Campe's didactic text. Indeed, it is a mistake to think of them as exchange relationships at all in any literal sense, because the depth of Friday's servitude means that he experiences the economy through expropriation and not exchange. Despite this, Edgeworth's theory sits comfortably within the marginalist canon by imagining away their differences and treating them as two autonomous beings whose market agency is decided upon by each independently solving his own choice-theoretic problem (see Brue and Grant 2013: 272). Crusoe and Friday are thus treated as equals who market institutions allow to come together economically as voluntary contracting partners. The history that Defoe provided to each might consequently appear to have been eliminated, but perhaps we should pause before coming to such a conclusion. The content of Mathematical Psychics reveals much about the continuing presence of the colonial settler as white-capitalist-cum-consumer when Edgeworth (2003 [1881]: 28) writes, matter-of-factly: 'The articles of contract: wages to be given by the white, labour to be given by the black'.

In Defoe's original novel, Friday is nothing more than an assemblage of body parts, labouring when he is told to do so in the manner in which Crusoe decides (Jooma 2001: 71). The economics textbooks' Friday figure is little different in the extent to which he continues to be used to illustrate a theory of exchange based on the principles of contract. He too is nothing more than a combination of latent labouring possibilities. He has no character as such, no ability to express the futility of being required to live his life this way, no agency beyond that which mandates certain forms of behaviour consistent with the world of constrained maximisation problems. Only one real difference is in operation here. In the textbooks it is the innate rationality of homo economicus he shares with Crusoe that causes Friday to act merely on the basis of his labouring capacities, whereas in Defoe's novel he is denied rationality entirely. There, Crusoe reserves the unconditional colonial right to work him as hard as he pleases, because Friday is not considered capable of deciding for himself where his preferences lie. At least one recent economics textbook remains faithful to the text of Defoe's novel in presenting Crusoe's choices in a much more expansive manner than Friday's, but this hardly makes for more comfortable reading than when the differences between the two are simply wished away. Frank Cowell (2005: 134) starts with the usual one-person example of Crusoe living alone. 'Now', he writes,

suppose that there is an extra person on the island. Although the preferences of this person (called 'Man Friday' after the original Robinson Crusoe book) ${ }^{3}$ play no rôle in the objective function and although he owns none of the resources, he plays a vital rôle in the economic model: he acts as a kind of intelligent slave to whom production can be delegated by Robinson Crusoe. We can then imagine the following kind of story. Crusoe writes down his marginal rates of substitution - his personal 'prices' for all the various goods in the economy - and passes the information on to Man Friday with the instruction to organise production on the island so as to maximise profits.

Perhaps the most that can be said in favour of this construction is that the myth of agential equality is no longer present.

Interestingly, Defoe's Crusoe's realisation that he is now free to enforce strictly asymmetrical contractual obligations onto other people comes before Friday ever makes it to the island. He had long yearned for company since the beginning of his solitary confinement, often driving himself beyond the bounds of his emotional coping capacity in his wish to have someone to talk to: 'I began to regret the want of conversation', he says, in a classic English understatement (146). What started as the desire for companionship, however, very quickly becomes the desire to place another into servitude: 'I fancied my self able to manage one, nay, two or three savages, if I had them, so as to make them entirely slaves to me' (204). Having already passed earlier in the novel from Crusoe-the-adventurer to 
Crusoe-the-settler, this is where he first begins to contemplate what it would be like to make the further transition from Crusoe-the-settler to Crusoe-the-master. ${ }^{4}$

Crusoe initially tutored himself to feel comfortable with his position in relationships of super- and subordination by playing them out in his head. Yet when he first spots a footprint in the sand and has to come to terms with the possibility that he may not be so alone after all, the fantasy of ownership transforms immediately into the ravages of fear: 'I stood like one thunder-struck' (162). This is in the first instance a bodily fear concerning his own preservation should the one footprint be a portent of many invaders with the power to overrun him (163). However, the fantasy of ownership is difficult to subdue, because it rapidly morphs into both an economic fear (that his right to property might no longer be guaranteed) and a fear of expectation (that this might be his best chance to seize another person as his possession). By the mid-point of the book, Crusoe-the-adventurer's piety for a life of 'meer wandring inclination' (27) has therefore clearly been superseded by Crusoe-the-settler's desire to cash in on 'all the mechanick exercises which my necessities put me upon applying my self to' (153). Yet as the footprint-in-the-sand episode demonstrates, he cannot persuade himself without sustained reflection that the next step to Crusoe-the-master carries sufficient rewards for the risks entailed in making others aware of his presence on the island. Seven years elapse in the story between Crusoe seeing the footprint in the sand and making his move to take Friday into his possession.

Despite this lengthy hesitation, though, the underlying plot unfolds in such a way that the reader knows it to be inevitable that he will make his move in the end. Long before the footprint-in-the-sand episode, Defoe had Crusoe practice his strategy for ultimately enslaving and claiming ownership over other humans on the animals with which he shares his island life. He first writes about thinking of himself in regal terms ('if I pleased, I might call my self king or emperor over the whole country which I had possession of' (139)) when replicating with the animals that survived the shipwreck with him the dining rituals that would have been recognisable were he back at home ('It would have made a stoick smile to have seen me and my little family sit down to dinner' (157)). The designation of his dining companions as 'family' is notable because of how seldom he mentions his actual family throughout his time as a castaway. The family theme is activated here so that the white settler can demonstrate to himself the legitimacy of his paternalistic rule. His technique for ensuring the animals' submission, then, shows him that it is possible to go beyond claiming property rights over land to also claiming other sensate beings as his possessions. What works on animals, he believes, will also work on the 'native' he intends to enslave. The equivocation over whether it would be worthwhile taking the risks that would be necessary to establish himself as a master on the island has not yet entered his head.

With his mind still uncluttered by hesitancy at this point in the story, Crusoe perfects initially on a young goat a weaning strategy that will later be used on Friday. The status of the goat changes from wild animal to domesticated family member as Crusoe discovers how to secure its dependence by withholding its food ('as I continually fed it, the creature became so loving, so gentle, and so fond, that it became from that time one of my domesticks also, and would never leave me afterwards' (124)). It would have had no difficulty finding itself enough to eat were it allowed to treat the island as a natural landscape, but Crusoe prevents it from doing so by using a tether to stop it roaming free. He makes it into his property through a willing subservience that operates via the fact that he alone provides the food that it needs to survive (Jooma 2001: 70). Crusoe subsequently repeats the trick after the dream of having a servant delivered to him turns into the reality of Friday's arrival. Friday is despatched, like a gun dog, to collect Crusoe's kills ('I pointed to him to run and fetch the bird I had shot, which he did' (214)). After this second success, Crusoe eventually comes to model all social relationships in terms of his subordinates' instinctive appreciation of his right to authority.

Eighteenth- and nineteenth-century readers were likely to have understood quite clearly that a 'native' would be next once Crusoe had successfully broken the goat's will. After all, at that time, animalistic analogues were introduced routinely when describing black people to white audiences (Bailey 2011: 58). The dividing line between domesticating animals and domesticating Friday 
would therefore have been somewhat blurred in Defoe's readers' minds. The colonial impulse received its assent from back home through attempts to render mysterious everyday practices not involving white people, and the image of the animalistic 'native' was indispensable to such a task (Canepari-Labib 2005: 70). As Gayatri Chakravorty Spivak (1999: 187) contends, it is a classic tactic for disqualifying racialised others from joining white people on the path to human self-determination. If they are physiologically only part-human, then they cannot have a claim on complete human psychological fulfilment. From this perspective, white settlers should not feel guilt when their choice to treat black people as enslavable makes impracticable the prospects of their complete human psychological fulfilment.

What, then, are we to make of Edgeworth's really rather blasé ascription of equal rights to Crusoe and Friday as voluntary contracting parties to the exchange relation? If his students had also read Defoe, Campe and various popular late nineteenth-century travelogues, they would not have been culturally disposed to view Crusoe and Friday as equal anything, let alone as equal manifestations of the neoclassical homo economicus. The 'Crusoe' and 'Friday' signifiers were already too well ingrained by then for the implications carried by their names to be simply magicked away in the absence of concerted attempts to systematically resituate the whole of the underlying story. Indeed, it is almost certainly for that reason that Campe chose to work within the structure laid down by those signifiers in the first place. Given the path from Campe to Edgeworth via Gossen and Jevons, it seems fairly safe to assume that their original meaning inscribed by Defoe was still largely in place when Edgeworth presented his readers with a pedagogical device populated by Crusoe-the-white-capitalist-cum-consumer and Friday-the-black-labourer-cum-servant. It would not have been particularly difficult for those readers to have recalled Crusoe's transition through the novel to the point at which he instinctively acts as a master.

\section{Xury, Friday and the nineteenth-century racialisation of enslavement}

When Defoe's readers reach the point in the text at which Crusoe claims rights of possession over Friday, they have already encountered 200 pages that are rich in references to the early eighteenth-century trade in enslaved persons. There is only a story to tell in the first place because of the shipwreck that occurred when Crusoe was seeking to profit from a slave-running voyage 'upon the coast of Guinea' (59). Moreover, Crusoe himself briefly passes into enslavement alongside the 'young Maresco' Xury (42), following an earlier seafaring mishap he describes in wantonly understated terms as a 'surprising change of my circumstances' (41). Much can be discerned about his instinctive assumption of the right to own other people from what he does to repay Xury's loyalty for assisting in their joint escape. It is a loyalty so selflessly exhibited that it previously moves Crusoe to proclaim that it 'made me love him ever after' (47). Yet this does not stop him from immediately selling his young friend straight back into enslavement, the only proviso being that his new owner, the Portuguese captain who picked them both up out at sea, 'would give the boy an obligation to set him free in ten years, if he turned Christian' (54). Crusoe seems to carry with him the early eighteenth-century Englishman's assumption of an established order of enslaver and enslaved. When it falls to him to enforce others' enslavement, he is entirely comfortable with what his European birth right allows him to do. His memory of once having been enslaved himself appears to evaporate completely.

However, Xury's position in this established order complicates somewhat the accompanying notion of racial hierarchy in Defoe's text. Crusoe could only have contemplated immediately returning him to the condition from which they had so recently joined forces to deliver themselves on the basis of assuming instinctively that he enjoyed privileges of birth that Xury did not. However, it does not appear to be an overly racialised marker that connotes Xury's innate inferiority, because nothing at all is made in the novel of his colour (Kugler 2012: 67). Defoe left Xury's ethnicity notably ambiguous. As Judith Still (2015: 270) suggests, he could be a direct descendant of Moors who had been expelled from Christian Europe by the early seventeenth century because of their Muslim faith, 
but equally enslaved Europeans in North Africa where Crusoe's and Xury's lives first became entwined often converted to Islam and referred to themselves as 'Maresco'. Either way, the primary distinguishing feature that renders Xury susceptible to being treated as Crusoe's possession is the fact that they pray to different gods (Doyle 2008: 188). Racial identifiers were by no means absent from the climate of opinion in which Defoe operated, as European Christians had developed more strictly delineated notions of 'white' and 'black' from the fifteenth century onwards (Sweet 1997: 159). However, as Jared Hickman (2010: 161) notes, this was always within the context of the co-constitution of race and religion. The trade in enslaved persons still had rather porous limits on matters of colour even up to Defoe's day, but the line was always drawn on co-religionists (Davis 1997: 9).

However, by the time the early marginalists first adopted the 'Crusoe' and 'Friday' signifiers, racial markers of difference had long become the standard justification for white people's continued sense of colonial entitlement (Müller-Wille 2015: 194). In a fascinating study of changing representations of Robinson Crusoe's main characters in the eighteenth century, Roxanne Wheeler (2000: 63-4) has shown how Xury was strategically re-raced to reflect the increasing consciousness amongst the English of 'blackness' as a symbol of innate inferiority. By the 1790s, and contrary to what it actually says in the book, Xury had come to be shown in illustrations accompanying Defoe's text as a black African, distinguishable from Crusoe both in dress and in ethnic background. Crusoe's first flirtation with the character of 'master' therefore latterly came to follow a much more overtly racialised template.

The same re-racing was also imposed upon Friday. Defoe's Crusoe sees a rationale for sparing Friday from his perceived fate at the hands of the cannibals precisely because he is not black. The first visual impression that Friday leaves on him is that the 'colour of his skin was ... of a bright kind of a dun olive colour, that had in it something very agreeable' (208). Friday's lighter skin complexion compared to that of his captors suggests to Crusoe that he might be converted from his heathen ways, whereas all hope is lost for the other 'natives'. He is therefore deserving of Crusoe's largesse, but they only of his bullets. Yet by the time that Campe had rewritten the Crusoe story that Gossen appropriated in the search for his homo economicus, Friday also appeared as indisputably black in the illustrations contained in reprinted versions of Defoe's novel. Those illustrations were used to try to enforce the general impression of how happy the existing population would be at the sudden arrival in their midst of 'superior' Europeans (Boulukos 2008: 38).

By the time that Defoe's characters entered economic theory, his sense of religious hierarchy had been blurred by Campe overlaying his own sense of racial hierarchy. This complicated the issue that later proved to be such a stumbling block for the early marginalists: namely, whether the neoclassical homo economicus embodies the genuine expression of agential free will (on which, see Jackson 2009: 127-8). Defoe simply gave Crusoe all of the characteristics that his readers could have been expected to associate with the right to exercise free will - white, Christian, male, English, colonist and he left it to them to draw their own conclusions. Campe added 'educated' to the list but proceeded no further. However, the question of whether anyone truly exercised free will had become a particular worry for economists from the 1830s onwards, especially in Britain, where Victorian intellectuals seemed to be unduly entranced by the possibility that behaviour could be attributed to a passive sensationalism (Jacyna 1981: 112). By the mid-nineteenth century, British studies in the science of mind tradition increasingly revolved around the apparently openly paradoxical claim that the mind was merely epiphenomenal of the body (Smith 2013: 42). Campe's parable that Gossen thought resembled his homo economicus revolved around Crusoe's apparently instinctive back-to-nature survivalism, but did this make him simply a captive of instinctive attention to the needs of the body? Moreover, if it did, how could Friday, who re-emerged in marginalist theory as just another Crusoe, be denied the right to respond to his bodily requirements by having his whole labouring body commodified? None of the first two generations of Anglo-Irish marginalists ever resolved this issue of agential free will. Edgeworth sidestepped it in favour of a utilitarianism that could not really comment on the matter (Barbé 2010: 99), whereas Jevons discussed the issue but did no more than fudge it (Kreisel 2012: 89). The ascription of free will to Crusoe by marginalist 
economists was therefore more than a little controversial in its own time. The related ascription of free will to Friday, which continues to this day within most of the subject field's textbooks, is doubly controversial given the effect of Defoe's original characterisation on the meaning carried by the 'Friday' signifier.

It was common practice in Jevons's and Edgeworth's day for the relationship between the imperial self and the colonised other to be modelled along the same paternalistic lines as the relationship between adults and children (Emberley 2007: 71). Imperial self-justification thus often centred on the projection onto others, in Uday Singh Mehta's (1990: 443) compelling phrase, of a 'civilizational infantilism' where agential free will was as yet undeveloped. The moral argument for the continued enactment of white privilege might be couched in terms of Platonic guardians, Burkean trustees or, as befitting the inspiration for Jevons's and Edgeworth's economic thinking, protecting the Benthamite greatest happiness of the greatest number. Whatever register was chosen, though, the same image applied of the child-like 'native' grateful for having its interests secured by an adult-like imperial master whose maturity grants unquestionable rights of determination (Chatterjee 2012: 179). Throughout the mid-to-late nineteenth century, economic theory mirrored colonial economic practice in enforcing what Iris Idelson-Shein (2014: 157) has called the 'discursive proximity between children and savages'.

It is therefore perhaps something rather more than coincidence that Crusoe and Friday figures initially entered economics specifically via Campe's didactic rewriting of the story for children. For Campe, anyone who had not received the gift of a formal education must, on that basis alone, be prey to the practices of savagery. The responsible adult must view children as little savages, he argued, if they are to help propel them into the adult world as competent individuals (Erlin 2014: 127). In Jevons's (2013 [1871/1911]: 35) hands, such competence translated economically into reasoning capacity grounded in 'a vague though powerful feeling of the future'. Defoe had already pointed the way in this regard. Across the whole of his fiction the same image appears of the 'native' as steeped in degeneracy but able to be educated into something more culturally tolerable when tutored how to lengthen their time horizons and place more emphasis on the future (Todd 2010: 92). Defoe enforced such perceptions onto the 'Crusoe' and 'Friday' signifiers by introducing reinforcing boundaries between master/servant and teacher/learner (O'Malley 2011: 191). The same passages in which Crusoe subordinates Friday also see him proclaim that Friday 'was the aptest schollar that ever was' (213).

From its earliest incarnation, then, the neoclassical homo economicus has been shot through with competing claims about the nature of adulthood that were fashionable in the late nineteenth century (Michals 2014: 50). One centred on the concept of economic rationality that the early marginalists were so eager to emphasise. There is only a small step from here to what Sylvia Wynter (2003: 260) describes as the archetypal individual of economic theory that today 'overrepresents itself as if it were the human itself'. Yet in the structured simplicity of his decision-making homo economicus is a denial of the other source of late nineteenth-century assumptions about adulthood: psychological complexity. It is surely ironic that Defoe's literary standing had already peaked on precisely this point when the early marginalists first widely used the central characters of his most famous book to populate their new theories (White 1982: 36). By the 1870s critics were already lining up to suggest that the plot lines involving Crusoe and Friday were overtly childish devices that begged the psychological intricacies of the adult world (Rogers 1972: 21). Moreover, before the end of Edgeworth's lifetime Campe's reworking of the story had been dismissed as 'twaddle ... didactics run mad' (Goodrick 1908: 682, 683). Nonetheless, for Crusoe to work as an example of the neoclassical homo economicus, he must be raised to the level of a fully functioning adult in his reasoning capacity and his farsightedness. More problematically still, for Friday to also work as another example of the neoclassical homo economicus, he must share this status of adult in a way that was flatly refuted in all retellings of Defoe's story prior to the 1870s. They all equated Friday's 'savagery' with his capacity for being moulded like a child, thereby disqualifying him from the economic rationality that might see him act as homo economicus. Cowell's (2005: 134) description of Friday 'as a kind of intelligent 
slave' therefore looks doubly difficult to swallow. Admittedly, this is one place within the economics textbooks - perhaps the one place - where Friday's enslavement is explicitly recognised and the ability to live a life bounded by neoclassical price functions is formally restricted to the white colonial settler. But to call him an 'intelligent slave' undermines the justification for his enslavement that persisted all of the way through until Edgeworth's time.

\section{Conclusion}

It has not been lost on critics just how much effort has been expended on rewriting Defoe's Robinson Crusoe in ways that meet the demands of modern political sensibilities (see Fallon 2016: 17-32). Every aspect of the novel that is susceptible to a postcolonial critique has been written anew in texts that seek to disturb Defoe's racialised account of super- and subordination. Given this, it seems to go seriously against the cultural trend when economics textbooks continue to use the 'Crusoe' and 'Friday' signifiers unreflexively. Economists still typically present a Crusoe figure as the prime example of a time- and place-transcendent economic 'everyman'. He can be nothing of the sort, because as a signifier he is irrevocably tied to the everyday structures of empire as they appeared to Defoe in the 1710s, Campe in the 1780 s and the self-styled marginalist revolutionaries in the 1870s. He carries with him the invocations of a specific time and a specific place as a white colonist settling land he claims via the barrel of a gun. More poignantly, with only the occasional exception, the economics textbooks also still tend to present Friday as merely another Crusoe figure, a second economic 'everyman' confronted with the same behavioural choices as the first. Again, though, he can be nothing of the sort, and it is not even necessary to have read the book to know this much about him. Any encounter with any variant of the Crusoe story is enough to ensure that the signifier 'Friday' always invokes the image of black servitude and enslavement. The 'Friday' signifier thus helps to propel the Crusoe character from settler to master. It is therefore in spite of everything that has been written about the original Crusoe and Friday in recent times that economists typically depict them as two entirely independent agents who engage in market exchange on the back of equal rights, equal capacities and equal insulation against whatever domineering thoughts the other may entertain. The imperial fantasy depicted by Defoe thus blurs really rather confusingly into an egalitarian fantasy at the hands of economics textbook writers.

There is much more of importance in this observation than merely saying that economists tend to get Crusoe and Friday wrong. Economics has largely withstood the accusation that the global financial crisis was every bit as much a crisis of its market models in order to maintain its privileged position as a source of social and political authority (Quiggin 2012: 27). It therefore matters how the beginning student is taught to think like an economist. The best-selling economics textbook writer, Gregory Mankiw (2011: 21), invites his readers to suspend their disbelief if they are to ever reach that lofty position, because the final destination can only be approached via learning how to manipulate relationships within the hypothetical Robinson Crusoe Economy. Must thinking like an economist, though, really entail imagining out of existence all relations of power in the hope that what remains will be a representation of a set of pristine market institutions? Is the possibility of a pure market logic so important to economic theory that the history of the 'Crusoe' and 'Friday' signifiers as symbols of the colonial settler and colonial master mindsets must be entirely disregarded? Make no mistake about it, the relationship between Crusoe and Friday is and always will be a relationship of racial oppression designed to illustrate the social acceptability to the early eighteenth-century mind of the imperial enterprise. No amount of postcolonial rewriting of Defoe's text will ever remove this element of the story, and nor will it ever try to do so. Defoe's overtly racist plot lines can only be revealed for what they are by leaving them there to act as a stimulus to their subsequent challenge. This makes economists' unreflexive use of Crusoe and Friday to illustrate the essential features of market theory more than a little worrying. Real-life markets are performed into existence at least in part on the back of prior adherence to economists' market theory (e.g. Callon 1998: 2; MacKenzie 2007: 62). If that theory leaves untouched the racial hierarchies that are 
locked into the signifiers 'Crusoe' and 'Friday', to what extent are market institutions similarly raced even before anyone attempts to exercise agency within them?

This is not an argument against the process of abstraction in economic theory. It is merely to make the more restricted case against presenting the theory of market exchange through named abstractions whose political history is expediently glossed over. To act upon this objection, however, threatens to bring economics full circle back to the 1850s. If anyone else could conceivably stand in for the neoclassical homo economicus, then presumably the Crusoe and Friday figures would be surplus to requirements. Yet the absence of viable alternatives is not a reason to act as if the original political purpose for which these figures were created can simply be ignored. Friday was disqualified from telling his own story for fear that it would lead to the inconvenient truth that empire was far from a benign process for those who saw their ancient lands settled. In destabilising Defoe's original plot lines numerous postcolonial writers have challenged their racist undertones by giving Friday his voice back. If the economics textbooks are to remain the last place where the racialised 'Crusoe' and 'Friday' signifiers are accepted uncritically, then the theory of market exchange they seek to popularise should become the next focal point of the decolonising spirit.

\section{Notes}

1. I would like to thank Lisa Tilley, Robbie Shilliam, John Holmwood, the participants at the original Raced Markets Workshop held at Warwick in December 2015 and NPE's anonymous referees for all their assistance in helping me to tighten up my argument.

2. All of the references to the text of Robinson Crusoe take this form and they relate to Defoe [1985 (1719)] listed in the bibliography.

3. It should be noted that, in Defoe's novel, Crusoe never once refers to 'Man Friday'. He names him 'Friday', as most people know, and he also frequently calls him 'my man' to reflect his status as master $(210,216,219,221,229,241$, $275,288,294)$. Contrary to popular folklore, however, 'Man Friday' is a misnomer.

4. I would like to thank one of NPE's anonymous referees for making me give greater attention to this issue.

\section{Acknowledgements}

I gratefully acknowledge the ESRC's ongoing support of my research.

\section{Disclosure statement}

No potential conflict of interest was reported by the author.

\section{Funding}

This article was written with financial assistance from an Economic and Social Research Council Professorial Fellowship. The Fellowship [grant number ES/K010697/1] supports the project, 'Rethinking the Market' (www.warwick.ac.uk/ rethinkingthemarket).

\section{Notes on contributor}

Matthew Watson is Professor of Political Economy in the Department of Politics and International Studies at the University of Warwick. He is also currently a UK Economic and Social Research Council Professorial Fellow.

\section{References}

Bailey, R. (2011), Race and Redemption in Puritan New England (Oxford: Oxford University Press).

Barbé, L. (2010), Francis Ysidro Edgeworth: A Portrait with Family and Friends, trans. by M. Black (Cheltenham: Edward Elgar).

Barro, R. (1997), Macroeconomics (Cambridge, MA: MIT Press).

Basov, S. (2017), Microeconomics with Spreadsheets (Singapore: World Scientific). 
Beveridge, T. (2013), A Primer on Microeconomics (New York: Business Expert Press).

Boulukos, G. (2008), The Grateful Slave: The Emergence of Race in Eighteenth-Century British and American Culture (Cambridge: Cambridge University Press).

Bowen, J. (1981), A History of Western Education, Volume III: The Modern West Europe and the New World (London: Routledge).

Brue, S. and Grant, R. (2013), The Evolution of Economic Thought, 8th ed. (Mason, OH: Cengage).

Callon, M. (1998), 'Introduction: The Embeddedness of Economic Markets in Economics', Sociological Review, 46 (S1), pp. 1-57.

Campe, J. H. (1789), The New Robinson Crusoe: An Instructive and Entertaining History for the Use of Children of Both Sexes (London: John Stockdale).

Canepari-Labib, M. (2005), Old Myths - Modern Empires: Power, Language and Identity in J. M. Coetzee's Work (Bern: Peter Lang).

Chatterjee, P. (2012), The Black Hole of Empire: History of a Global Practice of Power (Princeton, NJ: Princeton University Press).

Cowell, F. (2005), Microeconomics: Principles and Analysis (Oxford: Oxford University Press).

Crouch, C. (2016), The Knowledge Corrupters: Hidden Consequences of the Financial Takeover of Public Life (Cambridge: Polity Press).

Daston, L. (2004), 'Attention and the Values of Nature in the Enlightenment', in L. Daston and F. Vidal (eds), The Moral Authority of Nature (Chicago, IL: University of Chicago Press), pp. 100-126.

Davis, D. B. (1997), 'Constructing Race: A Reflection', William and Mary Quarterly, 54 (1), pp. 7-18.

Defoe, D. (1985 [1719]), Robinson Crusoe, ed. by A. Ross (London: Penguin).

Doyle, L. (2008), Freedom's Empire: Race and the Rise of the Novel in Atlantic Modernity, 1640-1940 (Durham, NC: Duke University Press).

Edgeworth, F. Y. (2003 [1881]), F. Y. Edgeworth: Mathematical Psychics and Further Papers on Political Economy, ed. by P. Newman (Oxford: Oxford University Press).

Emberley, J. (2007), Defamiliarizing the Aboriginal: Cultural Practices and Decolonization in Canada (Toronto: University of Toronto Press).

Erlin, M. (2014), Necessary Luxuries: Books, Literature, and the Culture of Consumption in Germany, 1770-1815 (Ithaca, NY: Cornell University Press).

Fallon, A. M. (2016), Global Crusoe: Comparative Literature, Postcolonial Theory and Transnational Aesthetics (London: Routledge).

Fuchs, E. (2004), 'Nature and Bildung: Pedagogical Naturalism in Nineteenth-Century Germany', in L. Daston and F. Vidal (eds), The Moral Authority of Nature (Chicago, IL: University of Chicago Press), pp. 155-81.

Goodrick, A. T. S. (1908) 'Robinson Crusoe, Impostor', Blackwood's Magazine, 183 (5), pp. 672-85.

Gossen, H. H. (1983 [1854]), The Laws of Human Relations and the Rules of Human Action Derived Therefrom, trans. by R. Blitz (Cambridge, MA: MIT Press).

Gottheil, F. (2013), Principles of Microeconomics, 7th ed. (Mason, OH: Cengage).

Grapard, U. (1995), 'Robinson Crusoe: The Quintessential Economic Man?', Feminist Economics, 1 (1), pp. 33-52.

Hewitson, G. (1999), 'Robinson Crusoe: The Paradigmatic “Rational Economic Man"', in U. Grapard and G. Hewitson (eds) (2011), Robinson Crusoe's Economic Man: A Construction and Deconstruction (Routledge: London), pp. 111-32.

Hickman, J. (2010), 'Globalization and the Gods, or the Political Theory of "Race"', Early American Literature, 45 (1), pp. 14582.

Hirshleifer, J., Glazer, A. and Hirshleifer, D. (2005), Price Theory and Applications: Decisions, Markets, and Information, 7th ed. (Cambridge: Cambridge University Press).

Hutchison, T. (1973), 'The "Marginal Revolution" and the Decline and Fall of English Classical Political Economy', in R. D. C. Black, A. W. Coats and C. Goodwin (eds), The Marginal Revolution in Economics: Interpretation and Evaluation (Durham, NC: Duke University Press), pp. 176-202.

Hymer, S. (1971) 'Robinson Crusoe and the Secret of Primitive Accumulation', Monthly Review, 23 (4), pp. 11-36.

Idelson-Shein, I. (2014), Difference of a Different Kind: Jewish Constructions of Race during the Long Eighteenth Century (Philadelphia, PA: University of Pennsylvania Press).

Jackson, W. (2009), Economics, Culture and Social Theory (Cheltenham: Edward Elgar).

Jacyna, S. (1981), 'The Physiology of Mind, the Unity of Nature, and the Moral Order in Victorian Thought', British Journal for the History of Science, 14 (2), pp. 109-32.

Jehle, G. and Reny, P. (2011), Advanced Microeconomic Theory, 3rd ed. (London: Pearson).

Jevons, W. S. (2013 [1871/1911]), The Theory of Political Economy, composite text of all four editions (Palgrave Macmillan, Basingstoke).

Jooma, M. (2001), 'Robinson Crusoe Inc(orporates): Domestic Economy, Incest, and the Trope of Cannibalism', in K. Guest (ed.), Eating their Words: Cannibalism and the Boundaries of Cultural Identity (Albany, NY: State University of New York Press), pp. 57-78.

Karagöz, Ufuk (2014), 'The Neoclassical Robinson: Antecedents and Implications', History of Economic Ideas, 22 (2), pp. 122. 
Kates, S. (2011) 'Introduction', in S. Kates (ed.), The Global Financial Crisis: What Have We Learnt? (Cheltenham: Edward Elgar), pp. 1-13.

Keen, S. (2013) 'Predicting the "Global Financial Crisis": Post-Keynesian Economics', Economic Record, 89 (2), pp. $228-54$. Kreisel, D. (2012), Economic Woman: Demand, Gender, and Narrative Closure in Eliot and Hardy (Toronto: University of Toronto Press).

Kugler, E. (2012), Sway of the Ottoman Empire on English Identity in the Long Eighteenth Century (Leiden: Brill).

Laidler, D. and Estrin, S. (1989), Introduction to Microeconomics, 3rd ed. (London: Philip Allan).

Leijonhufvud, A. (1976), 'Schools, "Revolutions", and Research Programmes in Economic Theory', in S. Latsis (ed.), Method and Appraisal in Economics (Cambridge: Cambridge University Press), pp. 65-108.

MacKenzie, D. (2007) 'Is Economics Performative? Option Theory and the Construction of Derivatives Markets', in D. MacKenzie, F. Muniesa and L. Siu (eds), Do Economists Make Markets? On the Performativity of Economics (Princeton, NJ: Princeton University Press), pp. 54-86.

Mankiw, G. (2011), Principles of Economics, 6th ed. (Mason, OH: Cengage).

Mankiw, G. and Taylor, M. (2006), Microeconomics (Mason, OH: Cengage).

Mas-Colell, A., Whinston, M. and Green, J. (1995), Microeconomics (Oxford: Oxford University Press).

McCloskey, D. (1996), 'The Economics of Choice: Neoclassical Supply and Demand', in T. Rawski et al., Economics and the Historian (London: University of California Press), pp. 122-58.

Mehta, U. S. (1990), 'Liberal Strategies of Exclusion', Politics and Society, 18 (4), pp. 427-54.

Michals, T. (2014), Books for Children, Books for Adults: Age and the Novel from Defoe to James (Cambridge: Cambridge University Press).

Morgan, M. (2012), The World in the Model: How Economists Work and Think (Cambridge: Cambridge University Press).

Müller-Wille, S. (2015), 'Linnaeus and the Four Corners of the World', in K. A. Coles, R. Bauer, Z. Nunes and C. Peterson (eds), The Cultural Politics of Blood, 1500-1900 (Basingstoke: Palgrave Macmillan), pp. 191-209.

Musgrave, F. and Kacapyr, E. (2001) Barron's How to Prepare for the AP Microeconomics/Macroeconomics Advanced Placement Examinations (Hauppauge, NY: Barron's Educational Series).

Naipaul, V. S. (2002), The Writer and the World: Essays, ed. by P. Mishra (London: Picador).

Nechyba, T. (2011), Microeconomics: An Intuitive Approach with Calculus (Mason, OH: Cengage).

O'Malley, A. (2011), 'Textual Transformations: The Case of Robinson Crusoe', in M. O'Grenby and K. Reynolds (eds), Children's Literature Studies: A Research Handbook (Basingstoke: Palgrave Macmillan), pp. 187-94.

Quiggin, J. (2012), Zombie Economics: How Dead Ideas Still Walk Among Us, pbk ed. (Princeton, NJ: Princeton University Press).

Rogers, P. (1972), 'Introduction', in P. Rogers (ed.), Defoe: The Critical Heritage (London: Routledge and Kegan Paul), pp. 1-30.

Said, E. (1994), Culture and Imperialism (New York: Vintage).

Samad, D. (2003), 'Literature', in M. Page and P. Sonnenburg (eds), Colonialism: An International Social, Cultural, and Political Encyclopedia - Volume One: A-M (Santa Barbara, CA: ABC-CLIO), pp. 345-7.

Shackle, G. L. S. (1992), Epistemics and Economics: A Critique of Economic Doctrines (New York: Transaction).

Sharma, P. (2007), Education Administration (New Delhi: A. P. H. Publishing Corporation).

Shavit, Z. (2006), 'Translation of Children's Literature', in G. Lathey (ed.), The Translation of Children's Literature: A Reader (Clevedon: Multilingual Matters Ltd), pp. 25-40.

Silberberg, E. (1995), Principles of Microeconomics (Denver, CO: Prentice-Hall).

Silvani, R. (2012), Political Bodies and the Body Politic in J. M. Coetzee's Novels (Münster: Verlag).

Smith, R. (2013), Free Will and the Human Sciences in Britain, 1870-1910 (London: Pickering and Chatto).

Snowdon, B. and Vane, H. (2005), Modern Macroeconomics: Its Origins, Development and Current State (Cheltenham: Edward Elgar).

Söllner, F. (2016), 'The Use (and Abuse) of Robinson Crusoe in Neoclassical Economics', History of Political Economy, 48 (1), pp. 35-64.

Spivak, G. C. (1999), A Critique of Postcolonial Reason: Toward a History of the Vanishing Present (Cambridge, MA: Harvard University Press).

Still, J. (2015), Derrida and Other Animals: The Boundaries of the Human (Edinburgh: Edinburgh University Press).

Stinespring, J. R. (2002), Mathematica for Microeconomics: Learning by Example (New York: Academic Press).

Sweet, J. (1997), 'The Iberian Roots of American Racist Thought', William and Mary Quarterly, 54 (1), pp. $143-66$.

Tarascio, V. (1972), 'Vilfredo Pareto and Marginalism', History of Political Economy, 4 (2), pp. 406-25.

Todd, D. (2010), Defoe's America (Cambridge: Cambridge University Press).

Varian, H. (1992), Microeconomic Analysis, 3rd ed. (London: W. W. Norton and Co).

Varian, H. (2014), Intermediate Microeconomics: A Modern Approach, 9th ed. (London: W. W. Norton and Co).

Watson, M. (2010), 'Competing Models of Socially-Constructed Economic Man: Differentiating Defoe's Crusoe from the Robinson of Neoclassical Economics', New Political Economy, 16 (5), pp. 609-26.

Watson, M. (2017), 'Rousseau's Crusoe Myth: The Unlikely Provenance of the Neoclassical Homo Economicus', Journal of Cultural Economy, 10 (1), pp. 81-96.

Watt, I. (1974), The Rise of the Novel: Studies in Defoe, Richardson and Fielding (London: Chatto and Windus). 
Weaver-Hightower, R. (2007), Empire Islands: Castaways, Cannibals, and Fantasies of Conquest (Minneapolis, MN: University of Minnesota Press).

Wheeler, R. (2000), The Complexion of Race: Categories of Difference in Eighteenth-Century British Culture (Philadelphia, PA: University of Pennsylvania Press).

White, M. (1982), 'Reading and Rewriting: The Production of an Economic Robinson Crusoe', in U. Grapard and G. Hewitson (2011) (eds), Robinson Crusoe's Economic Man: A Construction and Deconstruction (London: Routledge), pp. 15-41.

White, M. (1998), 'Robinson Crusoe', in J. Eatwell, M. Milgate and P. Newman (eds), The New Palgrave: A Dictionary of Economics, Volume 4 (Basingstoke: Macmillan), pp. 217-8.

Wynter, S. (2003), 'Unsettling the Coloniality of Being/Power/Truth/Freedom: Towards the Human, After Man, Its Overrepresentation - An Argument', New Centennial Review, 3 (3), pp. 257-337.

Zantop, S. (1997), Colonial Fantasies: Conquest, Family, and Nation in Precolonial Germany, 1770-1870 (Durham, NC: Duke University Press). 